\title{
Effects of Salinity and N on the Growth, Photosynthesis and N Status of Canola (Brassica napus L.)
}

\author{
Ahmad BYBORDI \\ Baku State University, Faculty of Biology, Soil Science Department, 23 Z. Khalilov Street, 370148 Baku, Azerbaijan; abaybordy@yahoo.com
}

\begin{abstract}
The effects of $\mathrm{NaCl}$ salinity and $\mathrm{N}$ on the growth, ion concentrations and photosynthesis ( $\mathrm{Pn}$ ) in three canola cultivars ('SLM ,' 'Okapi' and 'Licord') were investigated. The experiment was conducted with four $\mathrm{NaCllevels}(0,50,100$, and $150 \mathrm{mM}$ factoriallycombined with three $\mathrm{N}$ levels $\left(100,200,300 \mathrm{mgl}^{-1}\right)$ as $\mathrm{NH}_{4} \mathrm{NO}_{3}$ by adding to the half strength of Hoagland solution. The plants were growth in 121 pots filled with sand and perlite mixture $(1: 1)$ for 12 months. Salinity had a significant negative effect on all tratments, although the severity of the effect varied among the cultivars. High concentration of salinity $(150 \mathrm{mM})$ decreased the leaf area by $63 \%, 68 \%$ and $76 \%$ in cvs 'SLM ${ }_{046}$ ' and 'Licord' and 'Okapi' to that in control $\left(\mathrm{Na}_{0} \mathrm{~N}_{10}\right)$. The plants growth were improved at $200 \mathrm{mg} \mathrm{l}^{-1} \mathrm{~N}_{\text {concentration in }}$ cvs 'Licord' and 'Okapi', but it was reduced when the $\mathrm{N}$ concentration increased up to $300 \mathrm{mg} \mathrm{l}^{-1}$. The growth of 'SLM ' progressively increased with the increasing both salinity and $\mathrm{N}$ levels. Both Pn and transpiration rate were significantly reduced by the increase of salinity in all three cultivars. Increasing of N levels in the solution had no effect on Pn in various salinity levels in cvs 'SLM ' and 'Licord', but in 'Okapi' cv. Pn decreased as $\mathrm{N}$ level increased. Salinity in the root zone led to a significant decrease in both K concentration and K/ $\mathrm{Na}$ ratio in the leaves in all cultivars regardless of the $\mathrm{N}$ levels. Within each $\mathrm{N}$ level, leaf $\mathrm{Na}$ concentration increased and $\mathrm{K}$ concentration decreased as salinity concentration in the root zone increased from 50 to $150 \mathrm{mM}$. Nitrate reductase (NR) activity in $150 \mathrm{mM}$ treated plants decreased by 27\%, 58\% and 52\% in cvs 'SLM ' ' 'Licord' and 'Okapi' respectively. The decreased activity of NR by the increased $\mathrm{NaCl}$ was accompanied by a decrease in total $\mathrm{N}$ and nitrate uptake. The deleterious effects of salinity on the plants growth appeared to be as the result of the reduction in $\mathrm{Pn}, \mathrm{K} / \mathrm{Na}$ ratio and $\mathrm{NR}$ activity in the salinity treated plants. It can be concluded that under salinity conditions increasing $\mathrm{N}$ concentration up to $200 \mathrm{mg} \mathrm{l}^{-1}$ in salt-sensitive cultivars to salinity is favorite in counteracting the adverse effects of salinity but thefurther increase of $\mathrm{N}$ concentration $\left(300 \mathrm{mg} \mathrm{l}^{-1}\right)$ may be ineffective or even harmful for the canola growth. In salttolerant cultivars increasing $\mathrm{N}$ fertilization can be an effective tool to restore the decreased growth caused by high salinity.
\end{abstract}

Keywords: canola, salinity, nitrogen, photosynthesis, introduction

\section{Introduction}

Salinization of land has been received more attention bacause of increasing progressively throughout the world (Munns, 1993; Bybordi et al., 2010a, 1994; Kozlowski, 1997). It is estimated that approximately a third of the world's irrigated lands and half the lands in semiarid and costal regions are affected by salinization and 10 Million hairrigated lands are abandoned annually because of excessive salinity (Epstein et al., 1980). Of the 1.5 Billion ha that is cultivated, about $5 \%$ is affected by salt (Munns, 1993). Hence, it should be found an effective way to use saline lands by the cultivation of tolerant cultivars or other agrotechniques.

The significance of salinity for the agronomical and physiological aspects of plants is enormous. All salts can affect plant growth, but not all inhibit growth. Accumulation of both $\mathrm{Na}$ and $\mathrm{Cl}$ in the roots and aerial parts is most damaging to the plants often by inhibiting photosynthesis (Pn) (Munns, 1993; Flower and Yeo, 1988; White and Broadley, 2001). In the other cases, $\mathrm{Na}$ is the primary cause of ion- specific damage (such as reduction in $\mathrm{K}$ activity). The reduction in Pn in the salinity treated plants reported by many researchers (Downton, 1977; Ball and Farquhar, 1984; Behboudian et al., 1986).

Canola is one of the major crops in Mediterranean and in some regions of Middle East. The environmental adaptability of the canola and is tolerance to salinity (has made it possible for most of these new plantations to be established in arid and marginal areas. In the last few decades, much research has been devoted to the interaction between salinity and canola cultivation, and a significant body of information has accumulated on this topic, including descriptive material and data on the characteristics and mechanisms of salt tolerance in the canola (Ayers and Westcot, 1985; Kelin et al., 1994; Bybordi et al., 2010b; Bybordi and Tabatabaei, 2009).

Interaction between salinity and $\mathrm{N}$ affects growth and metabolism of plants in order to cope with the changes taking place in their environment (Papadopoulos and Rendig, 1983; Shenker et al., 2003). An apparent increase in salt tolerance has been noted when $\mathrm{N}$ levels supplied under saline conditions exceeded those that were optimum under non-saline conditions (Papadopoulos and Rendig, 1983; Bybordi et al., 2010c), implying that increased fertilization, especially $\mathrm{N}$, may ameliorate the del- 
eterious effect of salinity (Ravikovitch and Porath, 1967). However, factors involved in salinity-N interaction are not well documented. Reports on the effects of salinity on $\mathrm{N}$ metabolism have been focused on nitrate reductase (NR) activity. However, NR activity in plants has frequently been contradictory. NR was slightly inhibited by salinity in tomato roots, while leaf NR decreased sharply (Cramer and Lips, 1995). In the leaves of tomatoes and cucumbers, $\mathrm{NR}$ activity increased with exogenous $\mathrm{NO}_{3}$ concentration (Maritinez and Cerda, 1989).

For the canola there is not enough information concerning $\mathrm{N}$ assimilation. Therefore, the objective of this experiment was to determine the influence of different levels of $\mathrm{N}$ and $\mathrm{NaCl}$ on the growth, $\mathrm{Pn}$ and $\mathrm{N}$ assimilation. Furthermore, the feasibility of the increased $\mathrm{N}$ on the reduction in the opposing effects of salinity was studied.

\section{Materials and methods}

The canola (Brassica napus L.) cultivars 'SLM ', 'Licord' and 'Okapi' were transplanted into the pots filled with sand and perlite (1:1). The pots were kept into the glasshouse with natural sunlight and temperature range $30 \pm 3$ and $20 \pm 3^{\circ} \mathrm{C}$ in the day and at night, respectively. The experiment consisted of 12 treatments with four salinity concentration as $\mathrm{NaCl}(0,50,100,150 \mathrm{mM})$, factorially combined with three $\mathrm{N}$ concentrations $(100,200$, $300 \mathrm{mg} \mathrm{l}^{-1}$ ) as $\mathrm{NH}_{4} \mathrm{NO}_{3}$, each treatment being replicated four times. The solutions were prepared by adding either $\mathrm{NaCl}$ or $\mathrm{NH}_{4} \mathrm{NO}_{3}$ to half strength of Hoagland solution (Hoagland and Arnon, 1950). The solution $\mathrm{pH}$ was adjusted to 6.5 by adding $\mathrm{H}_{2} \mathrm{SO}_{4}$. Salt and $\mathrm{N}$ treatment were imposed on 1 February 2007, when the plant had developed three shoots of $25-30 \mathrm{~cm}$ in lenght. The plants were irrigated once a day with $15 \%$ extra solution to prevent the building up of $\mathrm{EC}$ in the root zone.

The leaves removed to measure leaf area and weight. The leaf area was measured using leaf areameter (Li-Cor, model Li-1300, USA). After weighing the leaves, they were dried at $80^{\circ} \mathrm{C}$ in an air forced oven for $48 \mathrm{~h}$.

Photosynthetic and transpiration rates of the midlamina of the youngest fully expanded leaves of two plants from each treatment were measured using a portable photosynthesis meter (Walz, Model HCM-1000, Germany). The flow rate and PAR were set to $800 \mathrm{~min}$ and $1500 \mu$ mol m $\mathrm{m}^{-2} S^{-1}$, respectively. Reference $\mathrm{CO}_{2}$ concentration was set to the inside of glasshouse. The time of measurement was between 9:00 and 14:00.

Nitrate reductase (NR) was measured in the young leaves (third or forth from the top, according to Klepper et al., 1971). The leaf tissue ( $0.2 \mathrm{~g} \mathrm{fw})$ was placed in reaction mixture containing $0.1 \mathrm{M}$ potassium phosphate buffer ( $\mathrm{pH}$ 7.5), $0.02 \mathrm{M} \mathrm{KNO}_{3}, 50 \%$ isopropanol, 0.05 chloramphenicol at $30^{\circ} \mathrm{C}$ for $1 \mathrm{~h}$ in the dark. The indicative Grease reagent containing 0.001 g.l naphtyl-ethylene diamine, $0.01 \mathrm{~g}$ Sulfanilic acid, and $0.9 \mathrm{~g}$ tartaric acid was added to each sample. The concentration of nitrite formed during the reaction was measured spectrophotometrically at $540 \mathrm{~nm}$.

Nitrate in tissue samples was determined by nitration of salicylic acid (Cataldo et al., 1975). Approximately $0.2 \mathrm{~g}$ of dried tissue powder was placed in $125 \mathrm{ml}$ container and $25 \mathrm{ml}$ of hot water was added. The samples were shaken for $30 \mathrm{~min}$ on a Wristaction shaker and filtered through Whatman No 42 filter paper. Nitrate in the filtered solution was determined by adding a $0.2 \mathrm{ml}$ sample aliquot containing $0.8 \mathrm{ml}$ of $5 \%(\mathrm{w} / \mathrm{v})$ salicylic acid $\mathrm{H}_{2} \mathrm{SO}_{4}$ mixture and $19 \mathrm{ml} 2 \mathrm{~N} \mathrm{NaOH}$. Samples were allowed to cool at room temperature for $1 \mathrm{~h}$, and developing color was measured at $410 \mathrm{~nm}$ by spectrophotometer (Motic, CL45240-00, China).

The concentration of total N, Na and $\mathrm{K}$ in the youngest fully expanded leaves were determined by Kjeldahl method and atomic absorption spectrophotometer, respectively (Perkine-Elmerse, Model 110, USA). Statistical analysis was made using analysis of variance in the SAS 8.2 software and the means were separated by LSD test at $5 \%$ level.

\section{Results}

The vegetative characteristics (leaf area, fresh and dry weight of leaves) as function of $\mathrm{N}$ concentration in the solutions at the various concentration of salinity are given in (Tab. 1) leaf area, fresh and dry weight of leaves was significantly reduced by the increasing of salinity $(150 \mathrm{mM})$. However, the reduction in growth varied at $150 \mathrm{mM} \mathrm{NaCl}$ according to cultivar so that the highest and lowest reduction was observed in cvs 'Okapi' and 'SLM 046 ' respectively. High concentration of salinity decreased the leaf area by

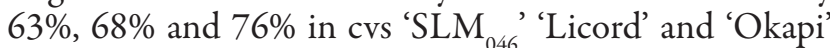
compare to that in control $\left(\mathrm{Na}_{0} \mathrm{~N}_{100}\right)$. Plant growth was improyed at $200 \mathrm{mg} \mathrm{N}$ concentration in cvs 'Licord' and 'Okapi' but it was reduced when the $\mathrm{N}$ concentration increased $(300 \mathrm{mg})$. The growth of 'SLM ${ }_{046}$ ' progressively increased with the increasing both salinity and $\mathrm{N}$ levels (Tab. 1). Interactive effect of salinity and $\mathrm{N}$ concentration on leaf area was significant in cvs 'Licord' and 'Okapi'. It indicated that increased $\mathrm{N}$ level up to $200 \mathrm{mg} \mathrm{l}^{-1}$ promote the leaf growth at both high and low salinity concentration. However, more increasing $\mathrm{N}$ level $\left(300 \mathrm{mg} \mathrm{l}^{-1}\right)$ significantly inhibited the leaf growth in both cvs 'Licord' and 'Okapi' particularly in salinity conditions. When the salinity was not limiting, the optimum $\mathrm{N}$ level varied with salinity. The rate of both $\mathrm{Pn}$ and transpiration rate were significantly reduced by the increase of salinity in all three cultivars (Tab. 2). The reduced Pn varied according to cultivar, so that the highest and lowest reduction in Pn was observed in cvs 'Licord' and 'SLM ${ }_{046}$ ' respectively. Increasing of $\mathrm{N}$ levels in the solution had no effect on Pn in various salinity levels in cvs 'SLM 046 ' and 'Okapi' but in cv 'Licord' Pn reduced as N level increased. 
94

Tab. 1. The effect of salinity and $\mathrm{N}$ levels on the vegetative characteristics of canola cultivars

\begin{tabular}{|c|c|c|c|c|c|c|c|c|c|}
\hline \multirow{2}{*}{$\begin{array}{c}\text { Treatment } \\
\mathrm{N}_{100}\end{array}$} & \multicolumn{3}{|c|}{ Leaf fw $\left(\right.$ g plant $\left.^{-1}\right)$} & \multicolumn{3}{|c|}{ Leaf dw $\left(\right.$ g plant $\left.^{-1}\right)$} & \multicolumn{3}{|c|}{ Leaf area $\left(\mathrm{cm}^{2}\right)$} \\
\hline & 'SLM ${ }_{046}^{\prime}$ & 'Licord' & 'Okapi' & $\mathrm{SLM}_{046}{ }^{\prime}$ & 'Licord' & 'Okapi' & 'SLM ${ }_{046}^{\prime}$ & 'Licord' & 'Okapi' \\
\hline $\mathrm{Na}_{0}$ & 137.50 & 31.73 & 19.83 & 13.65 & 9.08 & 7.19 & 927.39 & 660.09 & 167.88 \\
\hline $\mathrm{Na}_{50}$ & 124.98 & 24.36 & 7.01 & 10.30 & 6.84 & 2.34 & 1018.51 & 451.74 & 81.10 \\
\hline $\mathrm{Na}_{100}$ & 121.58 & 19.55 & 9.81 & 7.64 & 5.30 & 3.62 & 497.24 & 342.17 & 53.18 \\
\hline $\mathrm{Na}_{150}$ & 92.80 & 52.07 & 5.42 & 4.39 & 16.83 & 2.09 & 289.19 & 229.83 & 49.16 \\
\hline \multicolumn{10}{|c|}{$\mathrm{N}_{200}$} \\
\hline $\mathrm{Na}_{0}$ & 147.02 & 30.34 & 43.73 & 12.61 & 9.18 & 16.11 & 1291.57 & 614.71 & 378.85 \\
\hline $\mathrm{Na}_{50}$ & 140.93 & 36.25 & 14.45 & 15.78 & 10.91 & 4.41 & 1050.89 & 716.56 & 119.85 \\
\hline $\mathrm{Na}_{100}$ & 128.05 & 22.01 & 9.75 & 10.35 & 6.33 & 3.22 & 698.63 & 386.54 & 78.78 \\
\hline $\mathrm{Na}_{150}$ & 85.14 & 8.10 & 7.31 & 4.98 & 2.22 & 2.44 & 531.46 & 113.58 & 59.18 \\
\hline \multicolumn{10}{|c|}{$\mathrm{N}_{300}$} \\
\hline $\mathrm{Na}_{0}$ & 150.68 & 16.65 & 14.79 & 19.66 & 5.13 & 5.76 & 1350.18 & 311.32 & 122.64 \\
\hline $\mathrm{Na}_{50}$ & 138.88 & 29.73 & 24.05 & 15.41 & 9.81 & 8.26 & 1021.67 & 729.78 & 209.00 \\
\hline $\mathrm{Na}_{100}$ & 131.76 & 20.34 & 15.91 & 12.32 & 6.06 & 5.93 & 815.26 & 175.84 & 49.41 \\
\hline $\mathrm{Na}_{150}$ & 86.11 & 31.73 & & 7.66 & 9.08 & - & 486.45 & - & - \\
\hline \multicolumn{10}{|c|}{ Analysis of variance (F values) } \\
\hline $\mathrm{NaCl}$ & $8.3^{\circ}$ & $6.3^{\circ}$ & $15.4^{\prime \prime}$ & $10.7^{\prime \prime}$ & 15.6 & $6.4^{*}$ & $6.0^{\circ}$ & $10.2^{\cdots *}$ & $17.1^{*}$ \\
\hline $\mathrm{N}$ & $3.5^{*}$ & $3.7^{*}$ & $6.5^{* *}$ & $4.4^{*}$ & $4.4^{*}$ & $4.4^{*}$ & $1 . \operatorname{lns}$ & $5.6^{* *}$ & $7.2^{* *}$ \\
\hline $\mathrm{N}^{*} \mathrm{NaCl}$ & $0.2 \mathrm{~ns}$ & 3.0ns & $9.8^{*}$ & $0.6 \mathrm{~ns}$ & $9.3^{* *}$ & $2.6 \mathrm{~ns}$ & $0.1 \mathrm{~ns}$ & $6.0^{* *}$ & $11.7^{* *}$ \\
\hline
\end{tabular}

${ }^{*}$ Significance at 0.05 probability level, ${ }^{* *}$ Significance at 0.01 probability level, ns: non significance

The data of leaf ion concentration of the plants in relation to salinity and $\mathrm{N}$ levels are presented in (Tab. 3 and 4). Salinity in the root zone led to a significant decrease in both $\mathrm{K}$ concentration and $\mathrm{K} / \mathrm{Na}$ ratio in the plant tissue in all cultivars regardless of the $\mathrm{N}$ levels. The lower concentrations of $\mathrm{K}$ occurred in the treatments with the highest $\mathrm{NaCl}$ and $\mathrm{N}$ levels. Difference in $\mathrm{K}$ selectivity among cultivars was also observed in the $\mathrm{K} / \mathrm{Na}$ ratios (Tab. 3). Reduction in leaf $\mathrm{K} / \mathrm{Na}$ ratio was became more pronounced in cvs 'Licord' and 'Okapi' within each $\mathrm{N}$ level, leaf $\mathrm{Na}$ concentration increased and $\mathrm{K}$ concentration decreased as salinity concentration in the root zone increased from 50 to $150 \mathrm{mM}$. The interactive effect of salinity and $\mathrm{N}$ levels was significant in both cvs 'Licord' and 'Okapi' so that the increased $\mathrm{N}$ levels at high salinity concentration reduced $\mathrm{K} / \mathrm{Na}$ ratio. The highest concentration of $\mathrm{Na}$ in the roots was observed in cv. 'Licord' at $150 \mathrm{mM} \mathrm{Na}$ concentration.

Tab. 2. The effect of salinity and $\mathrm{N}$ levels on the both Pn and transpiration rate of canola cultivars

\begin{tabular}{|c|c|c|c|c|c|c|c|c|c|}
\hline \multirow{2}{*}{$\frac{\text { Treatment }}{\mathrm{N}_{100}}$} & \multicolumn{3}{|c|}{$\operatorname{Pn}\left(\mu \mathrm{mol} \mathrm{m}^{-2} \mathrm{~s}^{-1}\right)$} & \multicolumn{3}{|c|}{$\operatorname{Tr}\left(\mu \mathrm{mol} \mathrm{m}^{-2} \mathrm{~s}^{-1}\right)$} & \multicolumn{3}{|c|}{ Stom. Con. $\left(\mu \mathrm{mol} \mathrm{m}^{-2} \mathrm{~s}^{-1}\right)$} \\
\hline & 'SLM ${ }_{046}^{\prime}$ & 'Licord' & 'Okapi' & 'SLM ${ }_{046}^{\prime}$ & 'Licord' & 'Okapi' & 'SLM $_{046}^{\prime}$ & 'Licord' & 'Okapi' \\
\hline $\mathrm{NaCl}_{0}$ & 6.60 & 5.72 & 4.32 & 1.13 & 0.43 & 1.04 & 10.47 & 3.01 & 5.33 \\
\hline $\mathrm{NaCl}_{50}$ & 2.31 & 2.24 & 1.59 & 0.25 & 0.09 & 0.06 & 5.66 & 1.34 & 1.50 \\
\hline $\mathrm{NaCl}_{100}$ & 2.10 & 2.3 & 1.83 & 0.08 & 0.09 & 0.05 & 1.77 & 1.63 & 1.13 \\
\hline $\mathrm{NaCl}_{150}$ & 1.54 & 1.38 & 0.41 & 0.07 & 0.74 & 0.09 & 1.63 & 1.55 & 1.27 \\
\hline \multicolumn{10}{|c|}{$\mathrm{N}_{200}$} \\
\hline $\mathrm{NaCl}_{0}$ & 3.68 & 3.94 & 1.69 & 0.53 & 0.18 & 0.14 & 6.23 & 1.66 & 5.31 \\
\hline $\mathrm{NaCl}_{50}$ & 2.73 & 3.06 & 1.25 & 0.10 & 0.14 & 0.06 & 2.16 & 2.30 & 1.61 \\
\hline $\mathrm{NaCl}_{100}$ & 1.67 & 2.36 & 1.10 & 0.05 & 0.10 & 0.05 & 1.14 & 1.18 & 1.19 \\
\hline $\mathrm{NaCl}_{150}$ & 1.24 & 1.12 & 1.08 & 0.05 & 0.49 & 0.04 & 1.19 & 2.58 & 1.08 \\
\hline \multicolumn{10}{|c|}{$\mathrm{N}_{300}$} \\
\hline $\mathrm{NaCl}_{0}$ & 3.41 & 1.89 & 1.02 & 0.40 & 0.34 & 0.27 & 5.92 & 1.68 & 1.41 \\
\hline $\mathrm{NaCl}_{50}$ & 2.50 & 1.28 & 1.05 & 0.08 & 0.25 & 0.24 & 1.99 & 1.67 & 1.53 \\
\hline $\mathrm{NaCl}_{100}$ & 2.40 & 1.07 & 0.93 & 0.08 & 0.16 & 0.28 & 1.76 & 1.16 & 0.88 \\
\hline $\mathrm{NaCl}_{150}$ & 1.30 & 0.9 & - & 0.07 & 0.13 & - & 1.50 & 1.01 & - \\
\hline \multicolumn{10}{|c|}{ Analysis of variance ( $F$ values) } \\
\hline $\mathrm{NaCl}$ & $15.7^{\prime \prime}$ & $11.5^{\prime \prime}$ & $14.5^{\prime \prime}$ & 13.7 & $16.8^{\prime \prime}$ & $6.9^{\prime \prime}$ & $26.4^{\prime \prime}$ & $15.4^{\prime \prime}$ & $5.2^{*}$ \\
\hline $\mathrm{N}$ & $1.3 \mathrm{~ns}$ & $1.8 \mathrm{~ns}$ & $3.5^{* *}$ & $2.9^{*}$ & $3.3^{*}$ & $4.4^{*}$ & $6.6^{* *}$ & $2.7^{*}$ & $3.6^{* *}$ \\
\hline $\mathrm{N}^{*} \mathrm{NaCl}$ & $1.5 \mathrm{~ns}$ & $2.7 \mathrm{~ns}$ & $7.7^{* *}$ & $1.7 \mathrm{~ns}$ & 1.6ns & $6.5^{*}$ & $1.7 \mathrm{~ns}$ & $1.2 \mathrm{~ns}$ & $5.6^{* *}$ \\
\hline
\end{tabular}

${ }^{*}$ significance at 0.05 probability level, ${ }^{* *}$ significance at 0.01 probability level, ns: non significance 
Tab. 3. The effect of salinity and $\mathrm{N}$ levels on the vegetative characteristics of canola cultivars

\begin{tabular}{|c|c|c|c|c|c|c|c|c|c|}
\hline \multirow{2}{*}{$\begin{array}{c}\text { Treatment } \\
\mathrm{N}_{100}\end{array}$} & \multicolumn{3}{|c|}{$\mathrm{Na}$ concentration $\left(\mathrm{mg} \mathrm{g}^{-1} \mathrm{Dwt}\right)$} & \multicolumn{3}{|c|}{ K concentration $\left(\mathrm{mg} \mathrm{g}^{-1} \mathrm{Dwt}\right)$} & \multicolumn{3}{|c|}{$\mathrm{K} / \mathrm{Na}$} \\
\hline & 'SLM ${ }_{046}^{\prime}$ & 'Licord' & 'Okapi' & 'SLM ${ }_{046}$ ' & 'Licord' & 'Okapi' & 'SLM ${ }_{046}^{\prime}$ & 'Licord' & 'Okapi \\
\hline $\mathrm{NaCl}_{0}$ & 3.83 & 5.50 & 3.60 & 30.00 & 30.25 & 31.38 & 11.46 & 5.51 & 12.34 \\
\hline $\mathrm{NaCl}_{50}$ & 7.38 & 13.81 & 9.25 & 26.50 & 27.13 & 27.88 & 3.59 & 2.02 & 3.02 \\
\hline $\mathrm{NaCl}_{100}$ & 12.56 & 19.50 & 15.63 & 26.38 & 26.00 & 26.13 & 2.17 & 1.36 & 1.68 \\
\hline $\mathrm{NaCl}_{150}$ & 15.15 & 25.75 & 15.00 & 25.50 & 24.63 & 23.63 & 1.75 & 0.75 & 1.58 \\
\hline \multicolumn{10}{|c|}{$\mathrm{N}_{200}$} \\
\hline $\mathrm{NaCl}_{0}$ & 1.93 & 4.10 & 1.73 & 28.75 & 30.88 & 31.88 & 14.94 & 7.58 & 18.50 \\
\hline $\mathrm{NaCl}_{50}$ & 5.43 & 13.25 & 12.25 & 27.63 & 26.88 & 28.63 & 5.11 & 2.07 & 2.60 \\
\hline $\mathrm{NaCl}_{100}$ & 11.38 & 20.25 & 18.13 & 26.63 & 25.13 & 25.63 & 2.41 & 1.32 & 2.05 \\
\hline $\mathrm{NaCl}_{150}$ & 14.40 & 24.60 & 19.88 & 26.63 & 25.13 & 25.63 & 1.91 & 0.87 & 1.29 \\
\hline \multicolumn{10}{|c|}{$\mathrm{N}_{300}$} \\
\hline $\mathrm{NaCl}_{0}$ & 2.10 & 6.13 & 5.55 & 29.88 & 28.63 & 30.75 & 14.84 & 4.70 & 5.51 \\
\hline $\mathrm{NaCl}_{50}$ & 4.98 & 15.13 & 9.49 & 24.38 & 24.50 & 25.13 & 5.00 & 1.67 & 2.50 \\
\hline $\mathrm{NaCl}_{100}$ & 10.00 & 17.88 & 12.75 & 25.75 & 23.50 & 22.88 & 2.58 & 1.30 & 1.70 \\
\hline $\mathrm{NaCl}_{150}$ & 20.25 & - & - & 25.63 & - & - & 1.27 & - & - \\
\hline \multicolumn{10}{|c|}{ Analysis of variance ( $\mathrm{F}$ values) } \\
\hline $\mathrm{NaCl}$ & $59.2^{*}$ & $36.0^{*}$ & $15.4^{*}$ & 5.6 & $13.4^{*}$ & $20.3^{\cdots}$ & $53.5^{*}$ & $168.0^{* \cdots}$ & $51.4^{*}$ \\
\hline $\mathrm{N}$ & $0.8 \mathrm{~ns}$ & $0.2 \mathrm{~ns}$ & $1.3 \mathrm{~ns}$ & $0.6 \mathrm{~ns}$ & $1.2 \mathrm{~ns}$ & $0.5 \mathrm{~ns}$ & $1.2 \mathrm{~ns}$ & $3.0 \mathrm{~ns}$ & $2.8 \mathrm{~ns}$ \\
\hline $\mathrm{N}^{*} \mathrm{NaCl}$ & $2.0 \mathrm{~ns}$ & $1.4 \mathrm{~ns}$ & $0.9 \mathrm{~ns}$ & $0.5 \mathrm{~ns}$ & $0.3 \mathrm{~ns}$ & $0.3 \mathrm{~ns}$ & $0.5 \mathrm{~ns}$ & $7.6^{* *}$ & $8.8^{* *}$ \\
\hline
\end{tabular}

${ }^{*}$ significance at 0.05 probability level, ${ }^{* *}$ significance at 0.01 probability level, ns: nonsignificant

From the data given in Table 4 on both $\mathrm{N} \mathrm{NO}_{3}$ concentrations of all cultivars, it is clear that raising the $\mathrm{NaCl}$ concentration in the solution reduced $\mathrm{N}$ and $\mathrm{NO}_{3}$ concentrations of the leaves. The concentration of $\mathrm{N}^{3}$ in $\mathrm{cr}$ Mission was not affected by $\mathrm{N}$ levels but in cvs 'Licord' and 'Okapi' increasing $\mathrm{N}$ levels from 100 to $300 \mathrm{mg} \mathrm{l}^{-1}$ increased the $\mathrm{N}$ concentration in the leaves, but not statistically significant. Leaf $\mathrm{NO}_{3}$ concentrations in all cultivars was increased by raising $\mathrm{N}^{3}$ level up to $200 \mathrm{mg} \mathrm{l}^{-1}$ in the nutrient solution and higher concentration was ineffective in either $\mathrm{N}$ or $\mathrm{NO}_{3}$ concentration.

NR activity in $150 \mathrm{mM}$ treated plants decreased by $27 \%, 58 \%$ and $52 \%$ in cvs 'SLM ${ }_{046}$ 'Licord' and 'Okapi' respectively. Decreased activity of $\mathrm{NR}$ by $\mathrm{NaCl}$ stress was accompanied by a decrease in total $\mathrm{N}$ and nitrate uptake (Table 4). As shown in Table 4, both nitrate and total N concentration as well as NR activity was the highest in $\mathrm{NaO}$ and $\mathrm{N}_{200}$ treatments and decreased as the salinity in-

Tab. 4 . The effect of salinity and $\mathrm{N}$ levels on the vegetative characteristics of canola cultivars

\begin{tabular}{|c|c|c|c|c|c|c|c|c|c|}
\hline \multirow{2}{*}{$\frac{\text { Treatment }}{\mathrm{N}_{\mathrm{N}}}$} & \multicolumn{3}{|c|}{$\mathrm{N}$ con. $\left(\mathrm{mg} \mathrm{g}^{-1}\right)$} & \multicolumn{3}{|c|}{$\mathrm{NO}_{3}$ con. $\left(\mathrm{mg} \mathrm{g}^{-1}\right)$} & \multicolumn{3}{|c|}{$\mathrm{NR}\left(\mu \mathrm{mol} \mathrm{h}^{-1} \mathrm{~g}^{-1} \mathrm{Fwt}\right)$} \\
\hline & $\mathrm{SLM}_{046}^{\prime}{ }^{\prime}$ & 'Licord' & 'Okapi' & 'SLM ${ }_{046}^{\prime}$ & 'Licord' & 'Okapi' & $\mathrm{SLM}_{046}{ }^{\prime}$ & 'Licord' & 'Okapi' \\
\hline $\mathrm{NaCl}_{0}$ & 28.40 & 27.50 & 29.75 & 8.08 & 5.78 & 14.68 & 13.13 & 13.47 & 12.93 \\
\hline $\mathrm{NaCl}_{50}$ & 26.00 & 26.50 & 26.50 & 4.68 & 2.18 & 6.28 & 9.80 & 8.07 & 5.53 \\
\hline $\mathrm{NaCl}_{100}$ & 24.00 & 26.00 & 25.00 & 3.98 & 3.08 & 1.88 & 11.73 & 7.17 & 5.90 \\
\hline $\mathrm{NaCl}_{150}$ & 23.50 & 22.50 & 24.00 & 4.80 & 0.18 & 0.28 & 5.57 & 4.20 & 4.87 \\
\hline \multicolumn{10}{|c|}{$\mathrm{N}_{200}$} \\
\hline $\mathrm{NaCl}_{0}$ & 27.00 & 27.50 & 26.50 & 11.68 & 11.48 & 23.60 & 9.03 & 10.87 & 9.07 \\
\hline $\mathrm{NaCl}_{50}$ & 25.50 & 26.00 & 27.00 & 10.48 & 6.28 & 21.50 & 7.93 & 13.23 & 11.00 \\
\hline $\mathrm{NaCl}_{100}$ & 24.50 & 25.00 & 26.00 & 10.10 & 13.38 & 15.70 & 6.40 & 11.40 & 7.70 \\
\hline $\mathrm{NaCl}_{150}$ & 22.50 & 22.90 & 25.00 & 9.78 & 13.38 & 15.70 & 7.37 & 6.43 & 4.03 \\
\hline \multicolumn{10}{|c|}{$\mathrm{N}_{300}$} \\
\hline $\mathrm{NaCl}_{0}$ & 28.75 & 29.50 & 30.50 & 10.90 & 14.58 & 20.78 & 9.00 & 11.47 & 5.30 \\
\hline $\mathrm{NaCl}_{50}$ & 26.00 & 30.50 & 29.15 & 12.30 & 11.78 & 15.08 & 8.57 & 14.63 & 6.90 \\
\hline $\mathrm{NaCl}_{100}$ & 25.50 & 26.50 & 27.05 & 11.00 & 12.48 & 8.28 & 7.17 & 11.07 & 5.83 \\
\hline $\mathrm{NaCl}_{150}$ & 23.50 & - & - & 11.60 & - & - & 6.77 & - & - \\
\hline \multicolumn{10}{|c|}{ Analysis of variance ( $\mathrm{F}$ values) } \\
\hline $\mathrm{NaCl}$ & $11.8^{\prime \prime}$ & $5.0^{*}$ & 6.2 & $2.5^{\mathrm{ns}}$ & $4.5^{\circ}$ & $7.5^{\prime \prime}$ & $10.8^{\circ}$ & $6.8^{\mathrm{ns}}$ & $8.0^{* \prime}$ \\
\hline $\mathrm{N}$ & $0.35 \mathrm{~ns}$ & $4.0^{*}$ & $4.0^{*}$ & $11.6^{* *}$ & $4.7^{*}$ & $18.1^{* *}$ & $0.3 \mathrm{~ns}$ & $5.7 \mathrm{~ns}$ & $1.2 \mathrm{~ns}$ \\
\hline $\mathrm{N}^{*} \mathrm{NaCl}$ & $0.82 \mathrm{~ns}$ & $1.2 \mathrm{~ns}$ & $1.2 \mathrm{~ns}$ & $2.8 \mathrm{~ns}$ & $0.5 \mathrm{~ns}$ & $5.7^{*}$ & $0.6 \mathrm{~ns}$ & $0.4 \mathrm{~ns}$ & $0.4 \mathrm{~ns}$ \\
\hline
\end{tabular}

${ }^{*}$ Significance at 0.05 probability level, ${ }^{* *}$ Significance at 0.01 probability level, ns: non significance 
96

creased. Although a clear relationship was found between $\mathrm{Na}$ concentration of leaves and NR activity in all cultivars, the trend of decreasing NR caused by the increased salinity varied among the cultivars. Toxicity symptoms such as dead leaf edge and drop were recorded in cvs 'Licord' and 'Okapi' at $100 \mathrm{mM}$ which became more sever at $150 \mathrm{mM}$ and necrosis of stem tip was observed. The plants treated with $\mathrm{Na}_{150} \mathrm{~N}_{300}$ in cvs 'Okapi' and 'Licord' competely died at the end of the experiment. No symptoms of toxicity of salinity were observed in cv 'SLM ${ }_{046}$ '.

\section{Discussion}

Canola plants grown in the various levels of salinity were affected differently by the $\mathrm{N}$ rising in the nutrient solutions. The decline in leaf growth is an earliest response of the plants to salinity (Munns and Termaat, 1986). Leaf abscission at high salinity $(150 \mathrm{mM})$ occurred in cvs 'Licord' and 'Okapi' to further reduction in leaf area. This may caused by ions accumulation in the leaves, particularly old leaves (Grennway and Munns, 1980). The reduction in plant growth was due to the reduced leaf growth, which agrees with finding of Cramer (2002). At the highest concentration of salinity, however, $\mathrm{N}$ concentration not only had no effects on growth promotion, but reduced the plants growth. It implies that other factors (such as osmotic pressure) involving in plant growth. The direct factor might be salinity (such as osmotic effect, $\mathrm{Cl}$ or $\mathrm{Na}$ toxicity) as reported by Bongi and Loreto (1989); $\mathrm{Xu}$ et al. (2000). Reduction in both $\mathrm{K}$ and $\mathrm{K} / \mathrm{Na}$ at high salinity is another opposing effect of salinity, which impairs the function of $\mathrm{K}$ in the salinised plants. Devitt et al. (1981) and Jackson and Volk (1997). The increased salinity concentration in roots with increasing salinity in the root zone implies exclusion mechanism. This mechanism is most likely to act in low or moderate salinity as reported by Chartzoulakis et al. (2002). Remarkable genotypic differences were found on $\mathrm{Na}$ transport to leaves so that $\mathrm{Na}$ concentration of leaves in $\mathrm{cv}$. 'SLM 046 ' remained at low level at higher salinity concentration. It could be salt tolerance in canola is associated with the ability to reduce uptake and/or transport of saline ions.

The results clearly showed that a concentration dependent decrease in NR activity, nitrate and $\mathrm{N}$ concentration in the leaves. As NR is a substrate inducible enzyme (Marschner, 1995) and is decreased activity under salinization has been attributed by some researchers to decreased $\mathrm{NO}_{3}$ uptake by plants under salt stress (Lacuesta et al., 1990; Abdelbaki et al., 2000). The decreased of $\mathrm{NO}_{3}$ is accompanied by a high $\mathrm{Cl}^{-}$uptake (Parida et al., 2004) and low rate of xylem exudation in high osmotic conditions either by $\mathrm{NaCl}$ or other nutrients (Tabatabaei et al., 2004). Either the reduced $\mathrm{NO}_{3}$ uptake or translocation leads to lower $\mathrm{NO}_{3}$ concentration in the leaves, consequently reducing NR activity of leaves under salinity conditions. This finding agrees with Cramer and Lips (1995), who indicated that salinity may control $\mathrm{NR}$ activity throgh $\mathrm{NO}_{3}$ uptake since $\mathrm{NR}$ activity is largely determined by $\mathrm{NO}_{3}$ flux into the metabolic pool, rather than by tissue $\mathrm{NO}_{3}$ content itself. Most researchers have focused on the inhibitory role of $\mathrm{Cl}$ on $\mathrm{NR}$ activity, however the effect of $\mathrm{Na}$ on $\mathrm{NR}$ activity has not been known.

A clear relationship between $\mathrm{Na}$ concentration of leaves and NR reduction was observed; suggesting that $\mathrm{Na}$ may has an indirect effect on NR activity. It is most likely that in low level of $\mathrm{NaCl}$ treatments the increased concentration of $\mathrm{N}$ and $\mathrm{K}$ in the leaves may be responsible for favorable growth of the plants. In general, the results suggest that high salinity causes a depression in NR activity, nitrate and $\mathrm{N}$ concentration and $\mathrm{K} / \mathrm{Na}$ ratio in salt- sensitive cultivars and the adverse effects of salinity is become more pronounced in both high and low levels of $\mathrm{N}$ concentration in the solution. Increasing N from 100 to 200 $\mathrm{mg} \mathrm{l}^{-1}$ in the solution increases $\mathrm{NO}_{3}$ concentration in the leaves, however it was ineffective at $300 \mathrm{mg} \mathrm{l}^{-1}$ in restoring the decreased in the leaf $\mathrm{NO}_{3}$ caused by the increased salinity. This indicates that the effect of salinity could be an independent factor according to cultivar from that of $\mathrm{N}$ if that $\mathrm{N}$ is not the limited factor. The results clearly demonstrated that under salinity conditions increasing $\mathrm{N}$ fertilization in salt- sensitive cultivars is ineffective in counteracting the adverse effects of salinity, which may build up during the growing period or high salinity conditions. However, in salt-tolerant cultivars increasing $\mathrm{N}$ fertilization can be an effective tool to restore the decreased growth caused by high salinity.

The lowest inhibition was observed in ' $\mathrm{SLM}_{046}$ ', which had lower $\mathrm{Na}$ concentration in the leaves. The positive relationship between $\mathrm{K} / \mathrm{Na}$ and $\mathrm{Pn}$ suggests that the Pn rate is associated with salt content, which disagree with Tattini et al. (1995) who reported that Pn rate is independent from salt content. The dependence of salinity and Pn rate is varied according to cultivar as reported by Chartzoulakis et al. (2002). The reduction of Pn would be partly the rustle of the lower water availability in salinity conditions. Loreto et al. (2002) demonstrated that the limitation of Pn in salinity conditions in canola cultivars as a rustle of the low chloroplast $\mathrm{CO}_{2}$ concentration, caused by both stomatal and mesophyll conductance reduction. As shown in Tab. 2, the reduction of stomatal conductance and transpiration rate in cv. 'SLM ${ }_{046}$ ' occurred less than those in 'Licord' and 'Okapi', therefore this explain why 'SLM ${ }_{046}^{\text {' }}$ ' is apparently salt-tolerant. At high salinity in most cultivars, $\mathrm{Na}$ is transported and accumulated to the aerial parts, resulting toxicity symptoms.

The decline of $\mathrm{K}$ concentration under salinity conditions has been reported by Greenway and Munns (1980) and Devitt et al. (1981). This was also the case for canola particularly in salt-sensitive cultivars. Hence, maintain of relatively high $\mathrm{K}$ concentration or $\mathrm{K} / \mathrm{Na}$ ratio in the leaves acts an important role in regulation mono-valent cationic osmotic and physiological function of $\mathrm{K}$ in either Pn or $\mathrm{N}$ assimilation. 


\section{References}

Abdelbaki, G. K., F. Siefritz, H. M. Man, H. Welner, R. Kaldenhoff and W. M. Kaiser (2000). Nitrate reductase in Zea mays L under salinity. Plant Cell Environ. 23:15-521.

Ayers, R. S. and D. W. Westcott (1985). Water quality for agriculture. FAO Irrigation and Rainage Paper 29, Rev. 1, Rome 1-85.

Ball, M. C. and G. D. Farquhar (1984). Photosynthetic and stomatal responses of two angrove species, Avicennia marina and Aegiceras corniculatum, to long term alinity and humidity conditions. Plant Physiol. 1(74):1-6.

Behboudian, M. H., E. Torokfalvy and R. R. Walker (1986). Effects of salinity on ionic content, water relations and gas exchange parameters in some citrus scion rootstock combinations. Scie. Hort. 28:105-116.

Bongi, G. and F. Loreto (1989). Gas exchange properties of saltstressed Canola (Brassica napus L.) leaves. Plant Physiol. 90: 1408-1416.

Bybordi, A. and S. J. Tabatabaei (2009). Effect of Salinity Stress on Germination and Seedling Properties in Canola Cultivars (Brassica napus). Notulae Botanicae Horti Agrobotanici Cluj-Napoca 37(1):71-76.

Bybordi, A., S. J. Tabatabaei and A. Ahmadev (2010a). Effect of salinity on the growth and peroxidase and IAA oxidase activities in canola. J. Food Agric and Environ. 8(1):109112.

Bybordi, A., S. J. Tabatabaei and A. Ahmadev (2010b). The influence of salinity stress on antioxidant activity in canola cultivars (Brassica napus L.). J. Food Agric. and Environ. $8(1): 122-127$.

Bybordi, A., S. J. Tabatabaei and A. Ahmadev (2010c). Effects of salinity on fatty acid composition of canola (Brassica napus L.). J. Food Agric. and Environ. 8(1):113-115.

Cataldo, D. A., M. Haroon, L. E. Schrader and V. L. Youngs (1975). Rapid calorimetric determination of nitrate in plant tissues by nitration of salicylic acid. Common Soil Sci. Plant Ana. 6:71-80.

Chartzoulakis, K,. M. Loupassaki, M. Bertaki and I. Androulakis (2002). Effectsof $\mathrm{NaCl}$ salinity on growth, ion content and $\mathrm{CO}_{2}$ assimilation rate of six Canola cultivars. Scie. Hort. 96:235-247.

Cramer, G. R. (2002). Deferential effects of salinity on leaf elongation kinetics of three grass especies. Plant Soil 253: 233-244.

Cramer, M. D., S. H. Lips (1995). Enriched rhizopher $\mathrm{CO}_{2}$ concentration can ameliorate the influence of salinity on phydroponically grown tomato plants. Plant Physiol. 94:425-433.

Devitt, D., W. M. Jarrell and K. L. Steven (1981). Sodiumpotassium ratios in soil solution and plant response under saline conditions. Soil Sci. Am. J. 34:80-86.

Downton, W. J. S. (1977). Photosynthesis in salt stressed grapevines. Aust J Plant Physiol 4:183-192.
Epstein, E., J. D. Norlyn, D. W. Rush, R. W. Kingsbury, D. B. Kelley, G. A. Cunningaham and A. F. Wrona (1980). Saline culture of crops: a genetic approach. Science 210:339-404.

Flower, T. J. and A. R. Yeo (1988). Ion relations of salt tolerance, p. 392-414. In: Baker, D. D. and J. Halls (Eds.). Solute Transport in plant Cells and Tissue. Longman, Harlow.

Greenway, H. and R. Munns (1980). Mechanisms of salt tolerance in non-halophytes. Ann. Rev. Plant Physiol. 31:149-190.

Hoagland, D. R. and D. S. Arnon (1950). The water culture method for growing plants without soil. Calif. Agric. Exp. Stat. Cric. 374:1-32.

Jackson, W. A. and R. J. Volk (1997). Role of potassium in photosynthesis and respiration. In: Madison, W.S. (Ed), The role of potassium in agriculture. Am. Soc. Agr. 109-188.

Klepper, L. A., D. E. Flesher and R. H. Hageman (1971). Germination of reduced nicotinamide- adenine dinuclletide for nitrate reduction in green leaves. Plant Physiol. 48:580590.

Kozlowski, T. T. (1997). Responses of Woody plants to Flooding and salinity, Tree Physiology Monograph No.1. Heron Publishing Victoria, Canada.

Lacuesta, M., B. Gonzalez-Maro, C. Gonzale-Murua and A. Munoze-Rueda (1990). Temporal study of the effect of phosphinoihricin on the avctivity of glutamine synthetase, glutamate dehydrogenase and nitrate reductase in Medicago sative L. Plant Physiol. 136:410-414.

Maritinez, V. and A. Cerda (1989). Nitrate reductase activity in tomato and cucumber leaves as influenced by $\mathrm{NaCl}$ and $\mathrm{N}$ source. J. Plant Nutr. 12:1335-1350.

Munns, R. (1993). physiological processes limiting plant growth in saline soils: some dogmas and hypotheses. Plant Cell Environ. 16:15-24.

Munns, R. and A. Termaat (1986). Whole plant responses to salinity. Aust. J. Plant Physiol. 13:143-160.

Papadopoulos, I. and V. V. Rending (1983). Interactive effects of salinity and nitrogen on growth and yield of tomato Plants. Plant Soil 73:47-57.

Parida, A. K., A. B. Das and B. Mittra (2004). Effects of salt on growth, ion accumulation, phytosynthesis and leaf anatomy of the mangrove (Bruguiera parviflora). Trees 18:167-174.

Ravikovitch, S. and A. Porath (1967). The effect of nutrients on the salt tolerance of crops. Plant Soil 26:49-71.

Shenker, M., G. A. Bell and U. Shani (2003). Sweet corn response to combined nitrogen and salinity environmental stresses. Plant Soil 256:139-147.

Tabatabaei, S. J., P. Gregory and P. Hadley (2004). Uneven distribution of nutrients in the root zone affects the incidence of blossom end rot and concentration of calcium and potassium in fruits of tomato. Plant Soil 258:169-178.

Tattini, M. R., M. A. Gucci, C. Coradeschi, J. Ponzio and D. Everard (1995). Growth, gas exchange and ion content in Olea europaea plants during salinity stress and subsequent relief. Plant Physiol. 95:203-210. 